\title{
Standardization of protein-enriched cookies made from Tamarind seed flour
}

\author{
Farhat Sultana* \\ Department of Food Science and Nutrition, Community Science College and Research \\ Institute, Tamil Nadu Agricultural University, Madurai - 625104 (Tamil Nadu), India \\ Vijayalakshmi \\ Department of Food Science and Nutrition, Community Science College and Research \\ Institute, Tamil Nadu Agricultural University, Madurai - 625104 (Tamil Nadu), India

\section{Geetha} \\ Department of Differently Abled Studies, Community Science College and Research Institute, \\ Tamil Nadu Agricultural University, Madurai - 625104 (Tamil Nadu), India \\ Mini \\ Department of Biotechnology, Agricultural College and Research Institute Tamil Nadu \\ Agricultural University, Madurai - 625104 (Tamil Nadu), India \\ ${ }^{*}$ Corresponding author. Email: farukishwar@gmail.com
}

\section{Article Info}

https://doi.org/10.31018/ jans.v13iSI.2827

Received: March 22, 2021

Revised: June 10, 2021

Accepted: June 25, 2021

\section{How to Cite}

Sultana, F. et al. (2021). Standardization of protein-enriched cookies made from Tamarind seed flour. Journal of Applied and Natural Science, 13 (SI), 194 - 197. https://doi.org/10.31018/jans.v13iSI.2827

\begin{abstract}
Protein-energy malnutrition is one of the major public health problems in India affecting children under 5 years of age. The prevalence of underweight in children under 5 is $42.5 \%$ in India, being the highest globally. The need for low-cost supplemental food is vital under such conditions. This study aims to develop low cost and protein-rich value-added products from Tamarind seed flour. The incorporation of Tamarind seed flour $(50 \%)$ in the development of cookies exhibited a significant level of increase in protein in cookies. The protein content of Control cookies was $5.65 \%$ and Tamarind seed flour incorporated cookies was $11.26 \%$. This study depicted that Tamarind seed flour can be used as the replacement of conventionally used cereal flours to develop functional foods to curb protein-energy malnutrition
\end{abstract}

Keywords: Essential amino acids, Malnutrition, Protein-enriched cookies, Tamarind seed

\section{INTRODUCTION}

Tamarind (Tamarindus indica) is one of the most prominent trees in India. The leguminous tree is a multipurpose tree as all of its parts find application in various types of industries. From 250,000 tons of tamarind, 100,000 ton of tamarind seeds gets wasted (Singh et al., 2007). The tamarind polysaccharide commercially known as jellose finds application in both the pharmaceutical and food industry. The tamarind seed contains an optimum concentration of both essential and nonessential amino acids (de Lumen et al., 1986). The tamarind seed is a fair source of polyunsaturated fatty acids (Sou et al., 2017) and it contains potassium, calcium and phosphorous (Bagul et al., 2018).

The scope of tamarind seeds to replace conventional food additives and their nutrient and phytochemical-rich properties make it one of the inevitable raw ingredients of the food industry. The present study was aimed to examine the benefits of using tamarind seed flour to replace conventional flour in cookies.

\section{MATERIALS AND METHODS}

The present study was made at Community Science College and Research Institute, Tamil Nadu Agricultural University, Madurai, India.

\section{Processing of Tamarind seeds}

For facilitation of the decortication process, the tamarind seeds were sand roasted. The sand roasted seeds were hand pounded, winnowed and pulverised to tama- 
rind seed flour. The flour was sieved to minimise the size variation (Sultana et al., 2020).

\section{Standardization of protein-enriched cookies}

The standardization of cookies was made by incorporating tamarind seed flour at three different levels- $25 \%$, $50 \%, 75 \%$ with refined wheat flour. The optimum concentration for acceptance both in terms of organoleptic properties and nutritional properties was about $50 \%$. The cookies designated as $\mathrm{T}_{0}$ were the control and the cookies designated as $\mathrm{T}_{1}$ were $50 \%$ Refined wheat flour+ Tamarind seed flour. The formulation of cookies is given in Table 1.

\section{Flow chart for the preparation of cookies}



\section{Proximate analysis}

The proximate analysis was done using the Association of Official Analytical Chemists (2005) method. The proximate parameters analysed were: moisture, carbohydrate, protein, fat and ash

\section{Storage study}

The cookies were packed in high-density polypropylene packages $\left(P_{0}\right)$ and standup pouches $\left(P_{1}\right)$, and the difference in proximate composition during the storage period of 45 days was assessed. The impact of packaging material in terms of nutrient retention was also analyzed.

\section{Statistical analysis}

The statistical analysis was performed by AGRESAGDATA for one way analysis of variance. The results are the average of the four replicates and their Standard deviation.

\section{RESULTS AND DISCUSSION}

\section{Physical properties of cookies}

The physical properties of cookies before and after baking are given in Table 2 . The cookies from Tamarind seed had a diameter, thickness and spread ratio before and after baking was $11.16 \mathrm{~cm}, 6 \mathrm{~cm}, 1.86$ and $12.60 \mathrm{~cm}, 6.2 \mathrm{~cm}, 2.03$ respectively. The weight loss in the cookies was about $16.13 \%$. Fig. 1 shows the pictorial representation of the cookies, T1 was $50 \%$ refined wheat flour and $50 \%$ tamarind seed powder and $\mathrm{C}$ was the control.

Chakraborty et al. (2016) reported biscuits (50\% incor-

Table 1. Formulations of Tamarind seed flour incorporated cookies.

\begin{tabular}{lll}
\hline \multirow{2}{*}{ Composition } & Control & Level of incorporation (\%) \\
\cline { 2 - 3 } & $\mathbf{T}_{\mathbf{0}}$ & $\mathbf{T}_{\mathbf{1}}-\mathbf{5 0 \%}$ \\
\hline Refined Wheat flour(g) & 100 & 50 \\
Tamarind seed flour(g) & - & 50 \\
Sugar(powdered) (g) & 50 & 50 \\
Milk powder(g) & 5 & 5 \\
Vanilla powder(g) & 1 & 1 \\
Ammonium bicarbonate(g) & 0.5 & 0.5 \\
Shortening agent(g) & 50 & 50 \\
\hline
\end{tabular}

$\mathrm{T}_{0^{-}} 100 \%$ Refined Wheat flour; $\mathrm{T}_{1}-50 \%$ Tamarind seed flour+ $50 \%$ Refined Wheat flour

Table 2. Physical properties of Tamarind seed flour incorporated cookies.

\begin{tabular}{llllllllll}
\hline & \multicolumn{4}{c}{ Before Baking } & \multicolumn{4}{c}{ After Baking } \\
\cline { 2 - 10 } Treatments & $\begin{array}{l}\text { Diameter } \\
\mathbf{( c m})\end{array}$ & $\begin{array}{l}\text { Thick- } \\
\text { ness }(\mathbf{c m})\end{array}$ & $\begin{array}{l}\text { Sprea } \\
\text { d ratio }\end{array}$ & $\begin{array}{l}\text { Weight of } \\
\text { cookies } \mathbf{( g )}\end{array}$ & $\begin{array}{l}\text { Diameter } \\
(\mathbf{c m})\end{array}$ & $\begin{array}{l}\text { Thick- } \\
\text { ness } \mathbf{( c m})\end{array}$ & $\begin{array}{l}\text { Sprea } \\
\text { d ratio }\end{array}$ & $\begin{array}{l}\text { Weight of } \\
\text { cookies }(\mathbf{g})\end{array}$ & $\begin{array}{l}\text { Weight } \\
\text { loss }(\%)\end{array}$ \\
\hline $\mathrm{T}_{0}$ & 10.70 & 5.6 & 1.91 & 38.26 & 11.04 & 6 & 1.84 & 35.92 & 6.11 \\
$\mathrm{~T}_{1}$ & 11.16 & 6 & 1.86 & 38.85 & 12.60 & 6.2 & 2.03 & 32.58 & 16.13 \\
\hline
\end{tabular}


Table 3. Proximate composition of Tamarind seed flour incorporated cookies.

\begin{tabular}{lll}
\hline Chemical parameters & $\mathrm{T}_{\mathbf{0}}$ & $\mathrm{T}_{\mathbf{1}}$ \\
\hline Moisture (\%) & 2.45 & 1.62 \\
Carbohydrate $(\mathrm{g})$ & 66.23 & 72.52 \\
Protein $(\mathrm{g})$ & 5.65 & 11.26 \\
Fat $(\mathrm{g})$ & 26.36 & 22.98 \\
Fibre $(\mathrm{g})$ & 0.95 & 3.25 \\
Ash $(\mathrm{g})$ & 0.65 & 1.12 \\
\hline
\end{tabular}

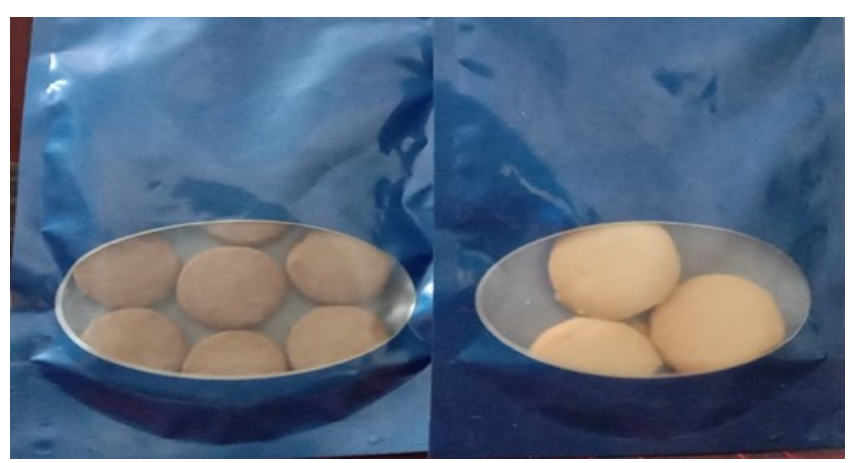

$\mathrm{T}_{0}$-Control

$\mathrm{T}_{1}-50 \%$ Refined wheat flour $+50 \%$ Tamarind Seed powder

Fig. 1. Showing Control $\left(T_{0}\right)$ and Tamarind seed cookies $\left(T_{1}\right)$ in Standup pouches.

poration of tamarind seed flour with wheat flour) that their diameter, thickness and spread ratio after baking was about $43.33 \mathrm{~mm}, 10.86 \mathrm{~mm}$ and 39.87 . In the present study, refined wheat flour was used instead of wheat flour. Refined wheat flour possessed better rheological properties when compared to wheat flour. Thus the difference in the rheological properties of refined wheat flour and wheat flour attributes to the difference in diameter, thickness and spread ratio of the control and Tamarind seed flour incorporated cookies.

\section{Proximate composition of cookies}

The moisture, carbohydrate, protein, fat, fibre and ash of Tamarind seed cookies was $1.62 \%, 72.52 \mathrm{~g}, 11.26 \mathrm{~g}$, $22.98 \mathrm{~g}, 3.25 \mathrm{~g}$ and $1.12 \mathrm{~g}$, respectively as specified in Table 3.

Chakraborty et al. (2016) reported biscuits (50\% incorporation of tamarind seed flour with wheat flour) that have protein, carbohydrate and fat content of $14.48 \mathrm{~g} / 100 \mathrm{~g}, 70.48 \mathrm{~g} / 100 \mathrm{~g}$ and $0.93 \mathrm{~g} / 100 \mathrm{~g}$, respectively. El-Gindyet al. (2015) reported that the biscuits made with $15 \%$ incorporation of Tamarind seed flour had moisture of $7.82+0.5 \mathrm{~g} / 100 \mathrm{~g}$, carbohydrate of $54.93 \pm 0.5 \mathrm{~g} / 100 \mathrm{~g}$, protein of $11.62 \pm 1.4 \mathrm{~g} / 100 \mathrm{~g}$ and fibre content of $3.79+0.3 \mathrm{~g}$ per $100 \mathrm{~g}$.

In the present study, the cookies standardization was done using the protocol as described by Kohajdová et al. (2014). The cookies preparation required a higher amount of shortening agent when compared to control, which resulted in better organoleptic properties than biscuits. The study observed a significant increase in carbohydrate, protein, and fibre content in tamarind seed powder cookies compared to the control. The increase in carbohydrate content can be attributed to the polysaccharide nature of Tamarind seed flour. The increase in protein content of Tamarind seed cookies states its potential to address protein-calorie malnutrition. The increase in fibre content of Tamarind seed cookies makes it a healthy dietary choice over conventional cookies

\section{Storage study of cookies}

The protein content in high-density polypropylene packages ranged from $11.26 \mathrm{~g}$ to $11.18 \mathrm{~g}$ during the storage period, while in the Standup pouch, the range was from $11.26 \mathrm{~g}$ to $11.19 \mathrm{~g}$ specified in Table 4. The standup pouches proved to better than high-density polypropylene packages in case of nutrient retention. The statistical analysis of the cookies' protein content revealed a significant difference $(0.69 \%$ in Standup pouches and $0.71 \%$ in high-density polypropylene packages) among the packaging materials, treatments, and days of storage.

Table 4. Changes in protein content of Tamarind seed flour incorporated cookies.

\begin{tabular}{lllll}
\hline \multirow{2}{*}{ Storage period } & \multicolumn{3}{c}{$\mathbf{P}_{\mathbf{1}}$} & $\mathbf{P}_{2}$ \\
\cline { 2 - 5 } & $\mathbf{T}_{\mathbf{0}}$ & $\mathbf{T}_{1}$ & $\mathbf{T}_{\mathbf{0}}$ & $\mathbf{T}_{1}$ \\
\hline 0 day & $5.65 \pm 0.06$ & $11.26 \pm 0.23$ & $5.65 \pm 0.11$ & $11.26 \pm 0.14$ \\
15 days & $5.62 \pm 0.17$ & $11.23 \pm 0.24$ & $5.64 \pm 0.18$ & $11.24 \pm 0.21$ \\
30 days & $5.60 \pm 0.06$ & $11.21 \pm 0.31$ & $5.62 \pm 0.03$ & $11.21 \pm 0.06$ \\
45 days & $5.58 \pm 0.06$ & $11.18 \pm 0.11$ & $5.60 \pm 0.03$ & $11.19 \pm 0.19$ \\
\hline
\end{tabular}

Values are means of 4 replicates. Means in the same column are significantly different at $P<0.05$ 


\section{Conclusion}

The present study concluded a significant increase in the protein content of the tamarind seed flour incorporated cookies compared to control. The changes in the protein content of the Tamarind seed flour incorporated cookies during storage was negligible. Owing to its protein-rich nature, the flour can replace conventional flour, making it a perfectly balanced and functional food. Further studies on efficient ways of processing tamarind seeds, value addition on tamarind seed, and the acceptable study levels on incorporating tamarind seed flour are desirable.

\section{Conflict of interest}

The authors declare that they have no conflict of interest.

\section{REFERENCES}

1. Association of Official Analytical Chemists (2005). Official Methods of Analysis of international 18th Ed., Association of Official Analytical Chemists (AOAC) International, Gaithersburg, MD, USA, Official Method 2005.08
2. Bagul, M.B., Sonawane, S.K. \& Arya, S.S. (2018). Bioactive characteristics and optimization of tamarind seed protein hydrolysate for antioxidant-rich food formulations. 3 Biotech., 8(4), 218.

3. Chakraborty, P., Chakraborty, N., Bhattacharyya, D.K. \& Ghosh, M. (2016). Effect of tamarind kernel powder incorporation in property and quality aspects of biscuit, bread and cake making. Archives of Applied Science Research, 8 (1), 30-39

4. De Lumen, B.O., Becker, R. \& Reyes, P.S. (1986). Legumes and cereal with high methionine/cysteine contents. Journal of Agricultural Food Chemistry, 34, 361-64

5. Kohajdová, Z., Karovičová, J., Magala, M. Kuchtová, V. (2014). Effect of apple pomace powder addition on farinographic properties of wheat dough and biscuits quality. Chemical Papers, 68(8), 1059-1065 http://dx.doi.org/1 0.2478/s11696-014-0567-1

6. Sou, D.S., Ba, C.A., WellingtondaSilva, O., JoseTeixeira, F. \& Helena Teixeira, G. (2017). Quantitative profile of fatty acids and tocopherols in tamarind seeds (Tamarindus indica L.) from different states of Brazil. Research Journal of Phytochemistry, 11, 118-128.

7. Sultana, B. F., Vijayalakshmi, R., Geetha, P. S., \& Mini, M. L. (2020). Optimization of value added products from under-utilized tamarind kernel powder. European Journal of Nutrition \& Food Safety, 12(11), 20-25. 